\title{
Gastric Dieulafoy lesion: a rare cause of massive haematemesis in an elderly woman
}

\author{
Jamie Clements, ${ }^{1}$ Barry Clements, ${ }^{2}$ Maurice Loughrey ${ }^{3}$
}

${ }^{1}$ General Surgery, Craigavon Area Hospital, Portadown, UK ${ }^{2}$ Department of General Surgery, Royal Victoria Hospital, Belfast, UK

${ }^{3}$ Department of Pathology, Royal Victoria Hospital, Belfast, UK

\section{Correspondence to}

Dr. Jamie Clements,

jclements06@qub.ac.uk

$\mathrm{BC}$ and $\mathrm{ML}$ contributed equally.

Accepted 1 March 2018

Check for updates

To cite: Clements J, Clements B, Loughrey M. BMJ Case Rep Published Online First: [please include Day Month Year]. doi:10.1136/ bcr-2017-223615

\section{DESCRIPTION}

A 78-year-old woman presented to her local accident and emergency department by ambulance, having collapsed following several episodes of voluminous fresh haematemesis with melaena. The patient had extensive medical comorbidities, suffering from type 2 diabetes mellitus, ischaemic heart disease, bronchiectasis and severe pulmonary hypertension. Three weeks previously she had undergone an uncomplicated total hip replacement for osteoarthritis and had been using non-steroidal anti-inflammatory drugs (NSAIDs) for analgesia. She had no history of gastroenterological disease.

The patient responded to initial resuscitative measures sufficiently to undergo oesophagogastroduodenoscopy. The gastroenterologist struggled to achieve any useful view of either stomach or duodenum due to the volume of haemorrhage, and aborted the procedure. The patient rapidly displayed signs of haemodynamic instability and deteriorated into a state of refractory hypovolaemic shock. She was intubated and ventilated.

The patient underwent laparotomy and antrotomy with duodenotomy, which showed no focal gastric or duodenal abnormality. Attempted preservation of the gastric fundus did not arrest the arterial haemorrhage and control was only achieved through total gastrectomy and oesophagojejunostomy. The gastric specimen is displayed, with bleeding source highlighted by arrow and inset (figure 1).

The list of differential diagnoses in this clinical situation is extensive (table 1). The most common cause of upper gastrointestinal bleeds (UGIBs) in this population is peptic ulceration, particularly posterior-wall duodenal ulcers, which can generate

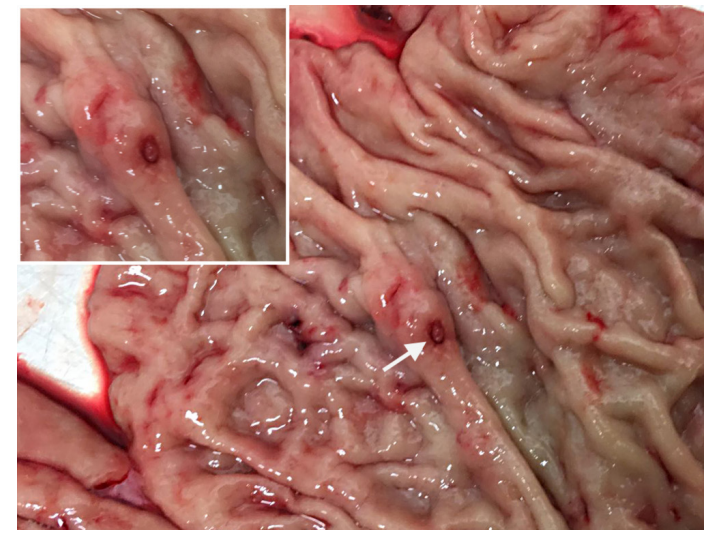

Figure 1 The resected gastric specimen demonstrating the Dieulafoy lesion. brisk haemorrhage from the gastroduodenal artery (a branch of the hepatic artery). This diagnosis may have been corroborated by the history of NSAID use; however, failure of endoscopy and angiography to identify a source of bleeding is typical of a more occult source.

The diagnosis is that of a Dieulafoy lesion or 'persistent calibre artery' of the stomach. A histomicrograph of the lesion is shown in figure 2, depicting classical features of normal surface gastric mucosa, aside from a haemorrhagic ulcer (arrow) penetrating a thick-walled arterial structure located within the superficial submucosa, representing the source of bleeding.

Dieulafoy lesion is a rare but well-recognised cause of UGIB. Lesions are most commonly located in the proximal stomach but have been reported throughout the gastrointestinal tract. ${ }^{1}$

Bleeding may be self-limiting and intermittent, or severe, the latter necessitating urgent intervention. Endoscopic detection is the diagnostic modality of choice, although endoscopic identification of the bleeding source may be extremely difficult, as bleeding is typically intermittent and surrounding mucosa is typically normal or demonstrates only a tiny ulcer. ${ }^{2}$

In the acute setting, profuse bleeding may obscure the endoscopic view. CT angiography may be a diagnostic strategy in the setting of acute bleeding, which may facilitate interventional radiology and arterial embolisation. Definitive

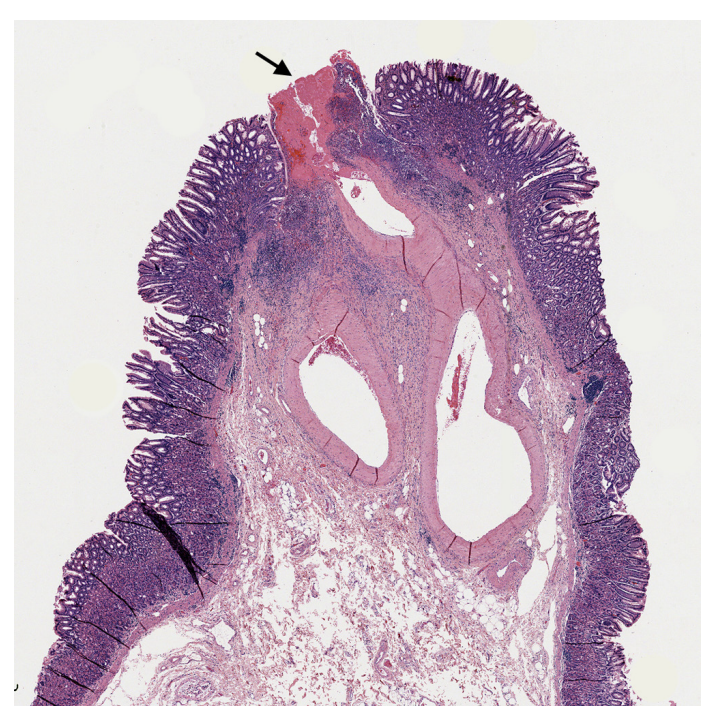

Figure 2 A histomicrograph of the same Dieulafoy lesion. 
Images in...

Table 1 Differential diagnoses of upper gastrointestinal bleeding

\begin{tabular}{|c|c|c|c|}
\hline & Microscopic features & Macroscopic features & Clinical features \\
\hline Dieulafoy lesion & $\begin{array}{l}\text { Normal surface gastric mucosa aside from defect } \\
\text { Histologically normal, tortuous submucosal } \\
\text { artery with an abnormally large arterial diameter } \\
(1-3 \mathrm{~mm}) \\
\text { Small mucosal defect varying from } 2 \text { to } 5 \mathrm{~mm} \text {, } \\
\text { with a fibrinoid necrotic base }\end{array}$ & $\begin{array}{l}\text { Mucosal erosion } \sim 1-5 \mathrm{~mm} ; 75 \% \text { within } 6 \mathrm{~cm} \text { of } \\
\text { the } \mathrm{GOJ} \\
\text { Attached thrombus may be seen } \\
\text { Absence of inflammation at the edge of the } \\
\text { mucosal defect }\end{array}$ & $\begin{array}{l}<1 \% \text { of UGIBs } \\
\text { Intermittent painless melaena and haematemesis } \\
\text { M:F } 2: 1\end{array}$ \\
\hline Duodenal ulcer & $\begin{array}{l}\text { Mucosal ulceration that can penetrate into } \\
\text { submucosa and muscularis propria, or perforate } \\
\text { onto the serosal surface; degree of surrounding } \\
\text { fibrosis relative to chronicity }\end{array}$ & $\begin{array}{l}\text { Mucosal defect } \sim 2-4 \mathrm{~cm} \\
\text { Diffuse, erythematous mucosal borders } \\
\text { Bleeding vessel or adherent clot sometimes } \\
\text { visible in ulcer base }\end{array}$ & \multirow{2}{*}{$\begin{array}{l}\text { 50\% of UGIBs } \\
\text { Symptoms: epigastric abdominal pain, belching, } \\
\text { anorexia, haematemesis } \\
\text { Risk factors: H. pylori infection, smoking, NSAIDs, } \\
\text { steroids, vagal tone (Cushing's ulcer), burns } \\
\text { (Curling's ulcer), Zollinger-Ellinson syndrome } \\
\text { (rare) }\end{array}$} \\
\hline Gastric ulcer & $\begin{array}{l}\text { Background mucosal changes depend on } \\
\text { aetiology, for example, Helicobacter pylori } \\
\text { gastritis or NSAID-related reactive gastropathy } \\
\text { (see below); most other causes, for example, } \\
\text { peptic, have non-specific microscopic features }\end{array}$ & $\begin{array}{l}\text { Mucosal defect } \sim 2-4 \mathrm{~cm} \\
\text { Smooth base with perpendicular borders } \\
\text { Bleeding vessel or adherent clot sometimes } \\
\text { visible in ulcer base }\end{array}$ & \\
\hline Oesophageal varices & $\begin{array}{l}\text { Large dilated submucosal veins } \\
\text { Expanded submucosa with elevation of mucosa } \\
\text { above normal tissue } \\
\pm \text { Haemosiderin-laden macrophages } \\
\pm \text { Fresh blood }\end{array}$ & $\begin{array}{l}\text { Dilated submucosal vessels in 'columns' } \\
\text { Commonly in distal oesophagus } \\
\text { Small (1-2 mm) or large }(1-2 \mathrm{~cm})\end{array}$ & $\begin{array}{l}5 \%-10 \% \text { of UGIBs } \\
\text { Haemorrhage risk: } \\
\text { Size of varices } \\
\text { Anticoagulants } \\
\text { Active alcohol use } \\
\text { Systemic infection } \\
\text { Volume resuscitation can precipitate further } \\
\text { haemorrhage-aim for stability and } \mathrm{Hb}>80 \mathrm{~g} / \mathrm{L}\end{array}$ \\
\hline Gastritis & $\begin{array}{l}\text { Microscopy depends on aetiology, for example, } H \text {. } \\
\text { pylori gastritis (usually antral but may be pan- } \\
\text { gastric; bacteria highlighted by histochemistry); } \\
\text { NSAID-related reactive gastropathy (foveolar } \\
\text { hyperplasia, fibromuscular lamina propria } \\
\text { expansion, paucity of inflammation); acute } \\
\text { gastritis (mucosal oedema, haemorrhage and } \\
\text { superficial erosions) }\end{array}$ & $\begin{array}{l}\text { Mucosal erythema and oedema, typically } \\
\text { associated with friability and superficial mucosal } \\
\text { 'breaks' (erosions) }\end{array}$ & $\begin{array}{l}10 \%-20 \% \text { of UGIBs } \\
\text { Heterogeneous phenomenon; the Sydney system } \\
\text { or the Operative Link for Gastritis Assessment } \\
\text { staging system may be useful in diagnostics/ } \\
\text { prognostics. } \\
\text { Common aetiology: H. pylori colonisation, } \\
\text { NSAIDs, alcohol, critical illness } \\
\text { Treatment should comprise } H \text {. pylori eradication, } \\
\text { antacid therapy and cytoprotective agents. }\end{array}$ \\
\hline Mallory-Weiss tear & $\begin{array}{l}\text { Longitudinal mucosal lacerations of the distal } \\
\text { oesophagus/proximal stomach, with surrounding } \\
\text { haemorrhage and acute inflammatory reaction }\end{array}$ & $\begin{array}{l}\text { Longitudinal mucosal lacerations with or without } \\
\text { active bleeding and adherent clot } \\
\text { Occasionally healing tears may appear as } \\
\text { superficial 'blood blisters' }\end{array}$ & $\begin{array}{l}\text { Up to } 10 \% \text { of UGIBs } \\
\text { More common in the young } \\
\text { Predisposing factors include alcoholism and } \\
\text { hiatus hernia } \\
\text { Haematemesis initiated by severe coughing or } \\
\text { retching } \\
\text { Non-bleeding tears may be managed } \\
\text { conservatively, with acid suppression and } \\
\text { antiemetics. }\end{array}$ \\
\hline
\end{tabular}

GOJ, gastro-oesophageal junction; Hb, haemoglobin; NSAID, non-steroidal anti-inflammatory drug; UGIBs, upper gastrointestinal bleeds.

management of catastrophic bleeding may require subtotal or total gastrectomy, and fatal cases are recognised. ${ }^{3}$

The patient recovered well in the initial postoperative period but succumbed some months later from refractory pulmonary hypertension.

Contributors JC: corresponding author and primary author; organised correspondence between all parties and prepared the final draft for submission; led the concept and design of the article and assimilated the various clinical images

\section{Learning points}

- Dieulafoy lesions are an extremely rare but potentially fatal cause of upper and lower gastrointestinal bleeding, and should be included in the list of differential diagnoses for gastrointestinal haemorrhage.

- Diagnosis and treatment can be treacherous, given the occult and intermittent nature of the presentation of the Dieulafoy lesion.

- Management should comprise supportive measures, followed by control of bleeding by endoscopy, interventional radiology or, failing these measures, surgery. and information from the respective consultants. ML: cosenior author; consultant pathologist; interpreted pathological specimens for submission and described a short vignette on the pathological appearances of Dieulafoy lesions for submission. BC: cosenior author; the consultant surgeon who performed the gastric resection and interpreted/prepared the surgical images for submission, in addition to supplying a short clinical vignette.

Funding The authors have not declared a specific grant for this research from any funding agency in the public, commercial or not-for-profit sectors.

Competing interests None declared.

Patient consent Obtained.

Provenance and peer review Not commissioned; externally peer reviewed.

(c) BMJ Publishing Group Ltd (unless otherwise stated in the text of the article) 2018. All rights reserved. No commercial use is permitted unless otherwise expressly granted.

\section{REFERENCES}

1 Veldhuyzen van Zanten SJ, Bartelsman JF, Schipper ME, et al. Recurrent massive haematemesis from Dieulafoy vascular malformations--a review of 101 cases. Gut 1986;27:213-22.

2 Chen $\mathrm{X}$, $\mathrm{Cao} \mathrm{H}$, Wang $\mathrm{S}$, et al. Endoscopic submucosal dissection for silent gastric Dieulafoy lesions mimicking gastrointestinal stromal tumors: Report of 7 cases-a case report series. Medicine 2016;95:e4829.

3 Gurzu S, Copotoiu C, Molnar C, et al. Lethal gastric hemorrhage from a caliberpersistent artery of the antrum - a branch of the right gastric artery. Hippokratia 2014:18:172-6. 
Copyright 2018 BMJ Publishing Group. All rights reserved. For permission to reuse any of this content visit http://group.bmj.com/group/rights-licensing/permissions.

BMJ Case Report Fellows may re-use this article for personal use and teaching without any further permission.

Become a Fellow of BMJ Case Reports today and you can:

- Submit as many cases as you like

- Enjoy fast sympathetic peer review and rapid publication of accepted articles

Access all the published articles

- Re-use any of the published material for personal use and teaching without further permission

For information on Institutional Fellowships contact consortiasales@bmjgroup.com

Visit casereports.bmj.com for more articles like this and to become a Fellow 